\title{
PENGEMBANGAN EKONOMI MASYARAKAT PEDESAAN MELALUI PENGENALAN AKUNTANSI DI KABUPATEN KEDIRI
}

\author{
Suhardi \\ Email : suhardi19@gmail.com
}

\begin{abstract}
Abstrak : Penelitian ini bertujuan untuk mengetahui penerapan akuntansi di pedesaan. Lemahnya kapasitas masyarakat pedesaan untuk mengakses pembiayaan dari lembaga keuangan. Metode penelitian yang digunakan adalah studi eksplorasi, yang dilakukan dengan menganalisis data yang dikumpulkan dari responden secara langsung dan Badan Pusat Statistik (BPS). Penguasaan dalam mengelola dan mencatat arus keuangan secara terorganisir dan dapat dipertanggungjawabkan relatif rendah akibatnya tingkat kepercayaan stakehorder berpengaruh negative. Praktik akuntansi pada usaha perekonomian masyarakat pedesaan di Kabupaten Kediri masih rendah, sehingga menyebabkan belum optimalnya pemanfaatan informasi akuntansi dalam pengembangan perekonomian masyarakat
\end{abstract}

Keywords: pengembangan ekonomi, penerapan akuntansi

\section{PENDAHULUAN}

Pengembangan perekonomian masyarakat merupakan salah satu tolok ukur keberhasilan pembangunan. Keberhasilan tentunya salah satu faktornya karena ketersediaan modal dalam mengoptimalkan pengembangan ekonomi. Salah satu wujud upaya pemerintah meningkatkan akses masyarakat terhadap permodalan adalah dengan menyelenggarakan program Kredit Usaha Rakyat (KUR), sampai saat ini sebagian masyarakat msih sulit untuk meningkatkan kapasitas usaha ataupun mengembangkan produk-produkyang mampu bersaing di pasar, apalagi produk jasa (kredit/pembiayaan) yang ditawarkan oleh perbankan saat ini, sebagian besar masih berupa kredit modal kerja dibandingkan kredit untuk investasi. Sebagian kalangan beranggapan bahwa keterbatasan akses ini lebih diakibatkan karena pelayanan kepada masyarakat pedesaan yang sebagian besar usaha kecil dan menegah masih dipandang kurang menguntungkan dan sebagai kegiatan yang beresiko tinggi bagi dunia perbankan.

Jika ditelusuri lebih jauh lagi masalah keterbatasan akses kredit lebih diakibatkan minimnya informasi yang dapat digunakan oleh calon investor ataupun kreditor dalam menilai dan memantau perkembangan usaha masyarakat pedesaan. Menurut Wahdini dan Suhairi (2006) yang menyimpulkan bahwa pihak bank tidak melihat adanya perbedaan antara usaha besar dengan UMKM, semuanya diwajibkan untuk memenuhi persyaratan termasuk harus menyediakan laporan Suhardi, adalah Dosen Prodi Akuntansi, Fakultas Ekonomi Universitas Nusantara PGRI Kediri 
keuangan untuk dapat dijadikan dasar dalam memberikan pinjaman kepada calon debitor. Disinilah pentingnya praktik akuntansi bagi UMKM, karena dengan diselenggarakannya praktik akuntansi secara tepat maka UMKM dapat menyediakan informasi yang lebih lengkap dan terstruktur terkait usaha dan posisi keuangannya.

Pada struktur dan budaya pedesaan khususnya pengusaha mikro dan kecil belum menyelenggarakan dan menggunakan informasi akuntansi secara maksimal dalam pengelolaan usahanya. Berdasarkan hal tersebut penelitian ini bertujuan untuk menganalisis sejauh mana problematika praktik akuntansi masyarakat pedesaan di Kabupaten Kediri serta keterkaitannya terhadap akses kredit.

\section{KAJIAN TEORI}

Penggunaan akuntansi manajemen tradisional untuk maksimisasi profit dan tujuan jangka pendek, telah dikembangkan menjadi pendekatan yang berfokus pada pencapaian kompetensi perusahaan yang berkelanjutan. Jika akuntansi manajemen tradisional yang berorientasi pada penyajian informasi bagi pengambilan keputusan berdasarkan aspek akuntabilitas, pengendalian biaya dan maksimisasi laba jangka pendek diutamakan bagi level operasional perusahaan, akuntansi manajemen strategik justru mengembangkan ruang lingkup akuntansi menjadi suatu proses penyajian informasi yang juga ditujukan pada perubahan perilaku, tidak saja bagi tingkatan operasional perusahaan namun juga tingkatan manajemen yang lebih strategis.

Pada saat perusahaan di seluruh dunia mengubah dirinya untuk kompetisi yang didasarkan pada informasi, kemampuan mereka untuk mengeksploitasi aktiva tidak berwujud (intangible asset) telah menjadi semakin positif dibandingkan kemampuan mereka untuk berinvestasi dan mengatur asset nyata (physical asset). Dalam akuntansi manajemen tradisional, pengukuran kinerja manajemen hanya didasarkan pada aspek-aspek keuangan semata, sebab ukuran keuangan dapat dengan mudah diperoleh berupa nilai kuantitatif yang berasal dari laporan keuangan. Sementara kinerja-kinerja non keuangan diabaikan karena dianggap sulit diukur dan memiliki kelemahan yang cukup menggangu yaitu ketidak mampuannya mengukur aktiva tak berwujud (intangible asset) dan harta-harta intelektual sumberdaya manusia (Rudiantoro, 2011).

Beberapa cara yang digunakan dalam manajemen tradisional untuk mengukur kinerja organisasi adalah dengan menggunakan ROI (return on Investment), EVA (Economic Value Added) dan lain-lain. Semua pengukuran tersebut menggunakan persfektif keuangan dalam jengka pendek, mungkin manajer dapat menghasilkan kinerja yang baik. Kinerja keuangan yang kurang baik saat ini, biasa disebabkan karena modal yang tersedia sangat terbatas. Akuntan menejemen akan menjadi lebih terlibat dalam menjalankan bisnis. Peran dari akuntan manajemen telah berjalan sesuai "business partner" manjadi seorang anggota dari team manajemen strategik. Pernyataan sebelumnya menyediakan bukti yang membandingkan peran akuntan dalam perluasan organisasi, dan akuntan semakin lama semakin berkesempatan menunjukkan kemampuan mereka dan meningkatkan nilai mereka bagi organisasi sebagai seorang anggota team 
manajemen strategik. Proses ini memungkinkan perusahaan mengintegrasikan perencanaan bisnis dan keuangan yang meliputi setting target, alokasi sumber daya, pelurusan inisiatif strategi dan penetapan kejadian-kejadian penting.

Praktik akuntansi pada suatu entitas ditandai dengan ketersediaan laporan keuangan pada entitas tersebut yang disusun secara sistematis dan didukung dengan bukti yang memadai. Untuk menghasilkan laporan keuangan maka berkaitan dengan ketersediaan sistem informasi akuntansi. Sistem informasi akuntansi merupakan sebuah susunan dari orang, aktivitas, data, jaringan dan teknologi yang terintegrasi yang berfungsi untuk mendukung dan meningkatkan operasi sehari-hari sebuah bisnis, juga menyediakan kebutuhan informasi untuk pemecahan masalah dan pengambilan keputusan oleh manajer.

\section{METODE}

Metode penelitian ini adalah studi eksplorasi, digunakannya metode eksplorasi pada penelitian ini untuk mengungkap secara komprehensif keterkaitan praktik akuntansi dengan pengembangan ekonomi pedesaan. Pada penelitian ini data primer dari pelaku usaha mikro dan menegah di pedesaan dan data sekunder diperoleh eksplorasi, yaitu melakukan analisis terhadap data yang berkaitan dengan perkembangan masyarakat yang bersumber dari BPS dan data yang telah dipublikasikan oleh media elektronik atau hasil penelitian sebelumnya baik yang telah dipublikasikan pada jurnal.

\section{PEMBAHASAN}

Dalam rangka membantu dan memberdayakan masyarakat pedesaan terutama petani dan peternak serta pelaku agribisnis, pemerintah telah meluncurkan berbagai kredit program dengan insentif yang diberikan kepada debitur terbatas berupa subsidi suku bunga, namun masih tetap melalui prosedur skim perbankan pada umumnya. Disamping itu, fasilitasi kredit program terfokus pada usaha budidaya dan belum banyak menyentuh aspek hulu dan hilir sektor pertanian, serta dengan plafon kredit yang masih relatif kecil. Dilain pihak para petani dan pelaku agribisnis masih terkendala dalam menyediakan persyaratan agunan tambahan dalam mengakses kredit/pembiayaan dari Perbankan. Sehubungan dengan hal tersebut diatas maka Departemen Pertanian bersama-sama Departemen lainnya telah menandatangani MoU dengan 6 (enam) Perbankan dan 2 (dua) Perusahaan Penjamin tentang Penjaminan Kredit/Pembiayaan kepada Usaha Mikro, Kecil, Menengah, dan Koperasi (UMKM-K). UMKM-K disini termasuk didalamnya sektor pertanian yang mempunyai usaha produktif, feasible tetapi belum bankable.

Sebagaimana diatur pada pasal 7 Undang-Undang Republik Indonesia Nomor 20 Tahun 2008 Tentang Usaha Mikro, Kecil Dan Menengah, Pemerintah dan Pemerintah Daerah menumbuhkan Iklim Usaha dengan menetapkan peraturan perundang-undangan dan kebijakan yang meliputi aspek pendanaan, sarana dan prasarana, informasi usaha, kemitraan, perizinan usaha, kesempatan berusaha, promosi dagang, dan dukungan kelembagaan. Sedangkan dunia usaha dan 
masyarakat berperan serta secara aktif membantu upaya pemerintah dan pemerintah daerah dalam menumbuhkan iklim usaha tersebut.

Berdasar data yang dilansir dari Kementerian Negara Koperasi \& UKM menunjukkan bahwa selama tahun 2006 - 2010 telah terjadi peningkatan sumbangsih UMKM terhadap PDB Nasional. Dengan penguasaan pangsa pasar UMKM sebesar 57,12 \% pada tahun 2010, jika dibandingan dengan tahun 2006 maka pada tahun 2010 telah terjadi peningkatan kontribusi UMKM terhadap PDB atas dasar harga berlaku sebesar 94,37\%, begitupula berdasarkan PDB atas dasar harga konstan 2000, peningkatannya pada tahun 2010 dibandingkan tahun 2006 telah mencapai $23,85 \%$. Sedangkan berdasarkan data total ekspor non migas nasional, sumbangsih UMKM pada tahun 2010 mencapai 15,81\% atau naik 42,12 dari tahun 2006. Selain itu, berdasarkan data investasi nasional, dengan pangsa pasar yang masih sekitar $48,20 \%$ dibandingkan total investasi nasional pada tahun 2010, kenaikan investasi atas dasar harga berlaku pada sektor UMKM dibandingkan tahun 2006.

Informasi akuntansi mempunyai peran penting untuk mencapai keberhasilan usaha, termasuk bagi usaha kecil (Megginson et al., 2000 dalam Pinasti, 2007). Informasi akuntansi dapat menjadi dasar yang andal bagi pengambilan keputusan dalam pengelolaan usaha kecil dan menengah, antara lain untuk keputusan penetapan harga, pengembangan pasar, termasuk untuk keputusan investasi (suhairi dkk, 2004) namun, dalam kenyataannya, pada umumnya pengusaha kecil tidak menyelenggarakan dan menggunakan informasi akuntansi dalam pengelolaan usahanya, kualitas laporan keuangan pada UMKM masih rendah.

Faktor penyebab atas tidak terselenggarakannya praktik akuntansi secara optimal dan tidak termanfaatkannya informasi akuntansi pada usaha masyarakat pedesaan di Kabupaten Kediri adalah sebagai berikut: 1) Tidak adanya penyelenggaraan dan penggunaan informasi akuntansi dalam kebanyakan pengelolaan usaha kecil ditentukan oleh persepsi pengusaha kecil atas informasi akuntansi. Bagi sebagian besar masyarakat, merasa tidak membutuhkan informasi akuntansi dan memandang akuntansi merupakan sesuatu yang sangat sulit untuk dilakukan dengan kata lain pengusaha kecil tersebut tidak pernah menggunakan informasi akuntansi maka informasi akuntansi dianggap sesuatu yang tidak penting, 2) Pada umumnya mereka tidak menguasai dan tidak mempraktekkan sistem keuangan yang memadai. Pada umumnya usaha kecil tidak atau belum memiliki pengetahuan dan kemampuan dalam mengelola catatan akuntansi secara ketat dan berdisiplin dengan pembukuan yang teratur, baik dalam bentuk harian, mingguan, bulanan, dan seterusnya, sehingga banyak diantara mereka yang belum memahami pentingnya pencatatan dan pembukuan bagi kelangsungan usaha, 3) Penangganan usaha tersebut masih lebih banyak dikelola secara perseorangan dengan manajemen seadanya.

Mengacu pada fakta bahwa tidak terselenggarakannya praktik akuntansi secara optimal dan tidak termanfaatkannya informasi akuntansi pada usaha masyarakat pedesaan selama ini bukanlah semata-mata merupakan kesalahan ataupun kekurangan para pelaku Usaha kecil dan menegah, tetapi juga dikarenakan belum optimalnya peran serta pemerintah dan masyarakat dalam mendorong praktik akuntansi di Usaha masyarakat kecil dan menegah di pedesaan. 
Dengan dimanfaatkannya informasi akuntansi dalam pengambilan keputusan investasi maka akan mendukung ketepatan wirausaha dalam mempertimbangkan konsekuensi keuangan atas keputusan yang diambil. Dalam hubungannya antara pengembangan usaha masyarakat pedesaan dengan pemerintah dan kreditur (Bank), penyediaan informasi akuntansi oleh UMKM juga sangat diperlukan. Hal ini sejalan dengan pernyataan Rudiantoro \& Siregar (2011), menyatakan bahwa salah satu teknik pemberian kredit yang paling banyak digunakan bank adalah financial statement lending yang mendasarkan pemberian kreditnya atas informasi keuangan dari debiturnya. Hal ini ditujukan untuk meyakinkan kelancaran pembayaran angsuran dan pengembalian pinjaman oleh calon debitur, selain pertimbangan karakter calon debitur, laporan keuangan yang menggambarkan pendapatan dan beban usaha serta aset, kewajiban dan modal yang dimiliki calon debitur menjadi pertimbangan utama keputusan diterima tidaknya permohonan kredit oleh Bank.

Untuk itu, dapat dikatakan bahwa praktik akuntansi sangat terkait dengan akses terhadap kredit, dengan praktik akuntansi yang memadai maka akan memudahkan pelaku usaha masyarakat pedesaan untuk memberikan keyakinan kepada bank atau calon kreditur bahwa usaha dapat dijalankan dan dibiayai/Feasible, pelaku usaha dapat memenuhi persyaratan kredit/pembiayaan/Bankable, dana yang diberikan dapat dipertanggungjawabkan IAccountable dan usaha yang dijalankan dapat menguntungkan.

\section{KESIMPULAN}

Praktik akuntansi pada usaha perekonomian masyarakat pedesaan di Kabupaten Kediri masih rendah, sehingga menyebabkan belum optimalnya pemanfaatan informasi akuntansi dalam pengembangan perekonomian masyarakat. Hal ini disebabkan oleh beberapa faktor, yaitu persepsi terhadap urgensi keberadaan informasi akuntansi bagi pelaku usaha, pengetahuan akuntansi, pertimbangan biaya-manfaat. Keterbatasan mengakses kredit, yang mana hal ini dikarenakan tidak tersedianya informasi akuntansi secara lengkap pada usaha masyarakat pedesaan dan karena tidak optimalnya praktik akuntansi di masyarakat. Untuk itu, dalam rangka mengembangkan usaha perekonomian masyarakat kecil dan menegah dan menciptakan usaha yang feasible, bankable, accountable, dan profitable maka sangat dibutuhkan partisipasi pemerintah dan masyarakat dalam mendorong diterapkannya praktik akuntansi di usaha masyarakat pedesaan secara tepat, implementatif dan berkelanjutan.

\section{DAFTAR PUSTAKA}

Pinasti, Margani. 2007. Penggunaan Informasi Akuntansi dalam Pengelolaan Usaha Para Pedagang Kecil di Pasar Tradisional Kabupaten Banyumas. Jurnal Ekonomi Bisnis dan Akuntansi 13(1). 
166 MODERNISASI, Volume 11, Nomor 3, Oktober 2015

Rudiantoro, Rizki \& Siregar, Sylvia Veronica. 2011. Kualitas Laporan Keuangan UMKM Serta Prospek Implementasi SAK ETAP. Makalah Simposium Nasional Akuntansi XIV. Aceh

Suhairi, Sofri Yahya \& Hasnah Haron. 2004. Pengaruh Pengetahuan Akuntansi Dan Kepribadian Wirausaha Terhadap Penggunaan Informasi Akuntansi Dalam Pengambilan Keputusan Investasi. Makalah Simposium Nasional Akuntansi VII. Denpasar.

Undang-Undang Republik Indonesia Nomor 20 Tahun 2008 Tentang Usaha Mikro, Kecil Dan Menengah.

Wahdini dan Suhairi. 2006. Persepsi Akuntan Terhadap Overload Standar Akuntansi Keuangan (SAK) Bagi Usaha Kecil Dan Menengah. Makalah Simposium Nasional Akuntansi IX. Padang. 